\title{
Land Use Change and Farmers' Sense of Place in Typical Catchment of the Loess Hilly and Gully Region of China
}

\author{
$\mathrm{Yi} \mathrm{Li}^{1}$, Yurui Li ${ }^{2} \mathbb{1}$, Bin Fang ${ }^{1, *}$, Lulu $\mathrm{Qu}^{3}$, Chongjing Wang ${ }^{1}$ and Wubo $\mathrm{Li}^{1}$ \\ 1 School of Geography, Nanjing Normal University, Nanjing 210023, China; 201301009@njnu.edu.cn (Y.L.); \\ wangchongjing@nnu.edu.cn (C.W.); 201302163@njnu.edu.cn (W.L.) \\ 2 Institute of Geographic Sciences and Natural Resources Research, Chinese Academy of Sciences, \\ Beijing 100101, China; liyr@igsnrr.ac.cn \\ 3 School of Public Policy and Administration, Chongqing University, Chongqing 400044, China; \\ qululu91@cqu.edu.cn \\ * Correspondence: 09199@njnu.edu.cn
}

Citation: Li, Y.; Li, Y.; Fang, B.; Qu,

L.; Wang, C.; Li, W. Land Use Change and Farmers' Sense of Place in Typical Catchment of the Loess Hilly and Gully Region of China. Land 2021, 10, 810. https://doi.org/ $10.3390 /$ land 10080810

Academic Editor: Nicholas Magliocca

Received: 29 June 2021

Accepted: 29 July 2021

Published: 1 August 2021

Publisher's Note: MDPI stays neutral with regard to jurisdictional claims in published maps and institutional affiliations.

Copyright: (c) 2021 by the authors. Licensee MDPI, Basel, Switzerland. This article is an open access article distributed under the terms and conditions of the Creative Commons Attribution (CC BY) license (https:// creativecommons.org/licenses/by/ $4.0 /)$.

\begin{abstract}
Clarifying the relationship between land use and farmers' sense of place on a micro scale is significant for enriching the perspective of research on human-environment relationships. Therefore, this paper analyzed land use change and the sense of place of farmers and further explored the interaction between them in the Yangjuangou catchment of Liqu Town in Baota District, Shaanxi Province from 1984 to 2020. The results indicated that: (1) the change in croplands was the most significant, i.e., its share in the total area decreased by $40 \%$, and the decrease in sloping fields was the highest. The average relative altitude of croplands has decreased. The change in ecological land was also more significant, showing an increasing trend. Overall, the exploitation of land resources has declined; (2) the intensity of the sense of place of local farmers fluctuated downwards. The intensity of place attachment and place dependence decreased, and the intensity of the place identity increased; and (3) the decline in the intensity of the place attachment and place dependence promoted the reduction of sloping fields, the growth of ecological land and abandoned fields. By comparison, the increase in ecological land and check dam land promoted an increase in the intensity of place identity for local farmers. This paper suggested that rural areas in the Loess Hilly and Gully Region should strengthen innovation in land use patterns and focus on sustainability of farmers' livelihoods, in order to promote the harmonious development of human-environmental relations.
\end{abstract}

Keywords: land use; sense of place; catchment; Loess Hilly and Gully Region

\section{Introduction}

The Loess Hilly and Gully Region (LHGR) represents the core area of the Loess Plateau in China, accounting for 33\% of the total area of the Loess Plateau. It is an important area for the transition of agriculture from farming to pastoral areas, as well as a densely populated area in Northwest China [1]. Due to the loose loess texture, sparse vegetation, concentrated and frequent extreme rainfall, LHGR has become one of the most serious regions for soil erosion in China and globally [2-6]. It is full of dense gullies that are usually U-shaped or $\mathrm{V}$-shaped. The broken terrain and limited available area led to increased land reclamation by local residents and the land became increasingly barren, forming a vicious circle. Overexploitation of natural resources has greatly damaged the ecological environment [7-9]. To prevent environmental deterioration and improve production and living conditions in the region, a number of ecological projects have been implemented since the founding of the People's Republic of China, including the check dam land Construction, the Comprehensive Management of Small Watersheds (CMSC), the Grain for Green Project (GGP) and the Gully Land Consolidation Project (GLCP). These projects had a significant impact on ecological restoration, agricultural production and diversification of farmers' livelihood. 
Small catchment areas are part of the River Basin System of the Loess Plateau. This is the main region of human activities in the LHGR and occupies the most extensive area [10]. Small catchments in the LHGR are often rural areas, so they are also typical rural systems [11]. Small catchments include almost all geomorphic types of LHGR, which are a source of soil and water loss on the Loess Plateau and the main region of return of farmland to forest and ecological management [12]. The LHGR small catchments investigation is also a response to China's Rural Revitalization Strategy.

Land is not only a complex of natural resource, but also the main space carrier of human activities $[13,14]$. Land use is the long-term or periodic management of land by people, which has certain economic and social purposes [15,16]. Land use change is a direct reflection of the interaction between human activities and the natural environment on the land surface $[17,18]$, which refers to the change in the quantity (area, proportion) and spatial pattern of land use types, i.e., dominant morphology changes of land use transition [19]. Related research combining land use change has been extensively conducted, which included the process, pattern, dynamic driving mechanism, and environmental effects of land use change [20-29]. Among them were more abundant research on the driving mechanism and environmental effects. The former mainly focused on the physical, social, and economic driving forces of land use change [20-22], while the latter mainly included the effects of land use change on hydrologic processes, climate change, and soil carbon stocks [27-29]. Land use change has become an important concern in research into global environmental evolution and sustainable regional development [30-32]. In LHGR, the implementation of a series of development strategies has led to an intense change in land use, and contradictions have been highlighted in the process of change. For example, extensive land reclamation and severe soil erosion, return of cultivated land to the forest and food security, leaving cultivated land and hollowing out of rural areas [33-36]. Therefore, the study of land use change is the focus of sustainable development in LHGR.

For centuries, human beings have had rich feelings for land. In rural regions, the land is not only the carrier of rural residents' emotion, but also the ultimate material guarantees of farmers' livelihood. The emotional connection between humans and land is called the sense of place in geography [37-39]. The sense of place is people's value and the cognition of land that comes from the interaction between people and the land and that is constantly evolving and changing [40,41]. The sense of place is in line with the people-oriented concept, which is an essential idea of human geography and can help people to further explore the social and cultural process of changing rural land use [42]. Referring to relevant research by domestic and foreign scholars $[43,44]$, this paper will explore the change in sense of place from three dimensions, including place identity (PI), place dependence (PD) and place attachment (PA). PI represents people's recognition of the affections of local natural and cultural features on individual development. PD represents the recognition of local production and living functions by people, while PA represents the emotional attachment of human beings to the land $[45,46]$.

Research on the sense of place is more abundant in Western countries and has become one of the important theories of geography. Research includes environmental science, land use change, rural development, urban research, leisure tourism, economic geography and other fields [42,44,47-49]. For example, Soini et al. used the concept of sense of place to investigate the relationship between people and landscape on the rural-urban fringe of Nurmijärvi in southern Finland [42]. Tapsuwan et al. predicted resident's intention to accept or reject land use planning decisions and groundwater policies by studying the sense of place (including notions of identity, attachment and dependence) of social groups living in Perth for many years [44]. Cross et al. believed that the place identity, the conservation ethic and economic dependence are distinct dimensions of the sense of place among the agricultural landowners, which can be used to predict the adoption of conservation easements. Chinese scholars have begun to focus on the sense of place of rural residents since the 21st century [49]. Xue et al. assessed the similarities and differences between land-lost and normal farmers' sense of place in land dependence and local attachment 
under the background of land circulation in Weibei Upland of Shaanxi Province [50]. Zhu et al. took Guangzhou's "Artist Village", Xiaozhou Village, as an example and assessed the evolution of the identities of local villagers and newcomer artists in the context of Guangzhou's urban spatial transformation [51]. In comparison, our knowledge of rural development from a comprehensive perspective of sense of place and land use remains weak, especially in LHGR.

In view of this, this study aims to analyze land use change and the sense of place of farmers and investigated the interaction between them in the Yangjuangou catchment of Liqu Town in Baota District, Shaanxi Province, where the relationship between people and environment has changed significantly. The research years selected in the study were 1984, 1998, 2012 and 2020, combined with remote sensing images and the different engineering impacts on land use. The study will provide a scientific reference for ecological construction, rural revitalization and harmonious development between people and environment in LHGR.

\section{Materials and Methods}

\subsection{Research Design}

This study was conducted as follows: (1) analysis of land use changes in the catchment based on remote sensing images during different periods. Cropland has the closest relationship with local emotions of farmers, so the evolutionary characteristics of the type structure, relative altitude and abandoned degree of cropland were analyzed. Furthermore, the degree of land use of the entire catchment was quantitatively analyzed in order to comprehensively evaluate the land use; (2) quantitative analysis of the sense of place from the perspective of PI, PD and PA; and (3) interaction between land use and sense of place, conducting a comprehensive study on the interaction between land use and sense of place based on quantitative data on land use and sense of place.

\subsection{Study Area}

The Yangjuangou catchment is located $14 \mathrm{~km}$ east of Yan'an city, with an area of $2.64 \mathrm{~km}^{2}$. The study region is the secondary branch gully of the Yanhe River and the primary tributary of the Nianzhuanggou catchment. The loess soil is the main soil developed from the loess parent material. It has loose and uniform texture and high erodibility. The area is crossed with gullies, and the gully density is $2.74 \mathrm{~km} / \mathrm{km}^{2}$, the altitude of the area is from $1050 \mathrm{~m}$ to $1295 \mathrm{~m}$ [52]. The construction of the check dam land caused to some extent a change in the shape of the valley, including a decrease in the vertical gradient of the channel, an increase in the base level of erosion and a decrease in the relative altitude difference. The catchment has a semiarid continental monsoon climate. The average multi-annual precipitation is $535 \mathrm{~mm}$ and it is mainly concentrated from July to September, accounting for more than $60 \%$ of total annual precipitation [53]. The total annual solar radiation is $5800 \mathrm{KJ} \mathrm{cm}^{-2}$, the annual sunshine is $2563 \mathrm{~h}$, and the mean annual temperature is $9.4{ }^{\circ} \mathrm{C}$. Artificial Robinia pseudoacacia is the main vegetation in the area (Figure 1).

In 2020, there were 186 registered inhabitants, with about 40 permanent residents with average age of over 45. The average income of each household was about 30,000 CNY. Check dam land and terraces were the main types of croplands with the main crops of foxtail millet, corn and potatoes. The main types of land use were forests, shrubs, grassland, check dam land and terraces. Considering the following reasons, the Yangjuangou catchment was selected as the case study area: (1) the Yangjuangou catchment, a traditional agricultural village, is characterized by a large number of labor migrations, rural hollowing and aging, which can be considered a microcosm of many rural areas in LHGR; (2) since economic reforms and open door policy, the catchment has experienced a number of ecological and livelihood projects, including the check dam land Construction, the Comprehensive Management of Small Watersheds, the Grain for Green Project, the Gully Land Consolidation Project, and the Village Combination Project ${ }^{1}$. As a result, there have been major changes in the natural and cultural landscape of the case study area; and (3) the research 
team has been conducting continuous field observations and household surveys in the catchment since 2012, so the context of the catchment development is clearly understood.
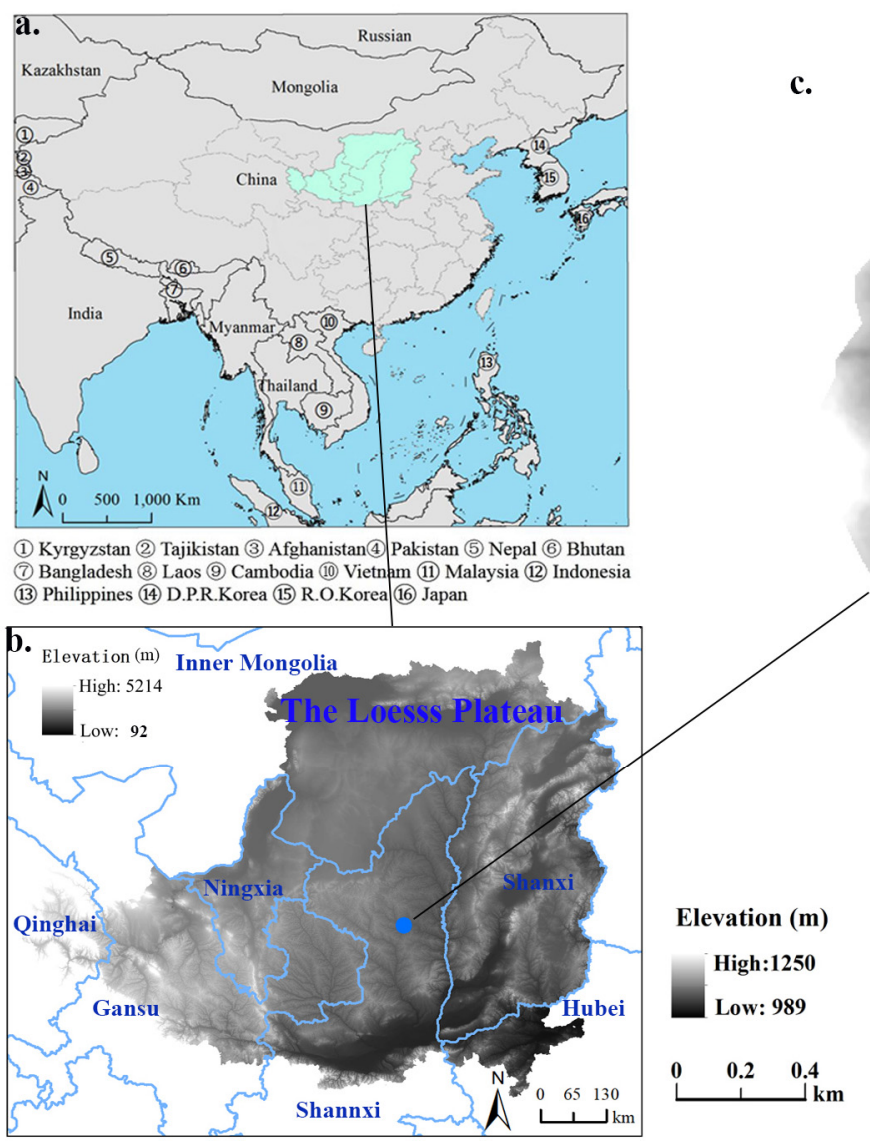

c.

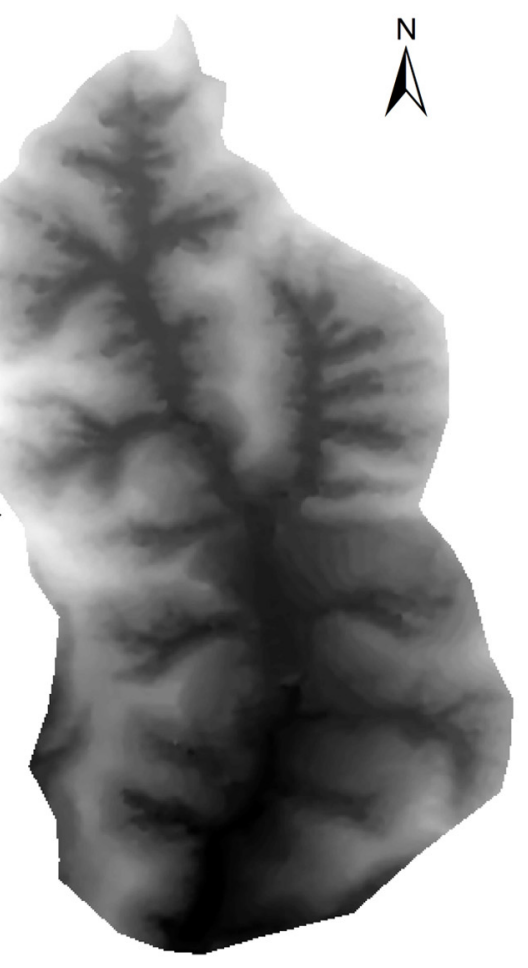

The Study Area

Figure 1. The geographical location and DEM of the study area. (a) Location of the Loess Plateau; (b) location of the study area; (c) boundary and altitude of the study area.

\subsection{Data Sources and Preprocessing}

\subsubsection{Sources of Land Use Data}

Land use data were obtained from remote sensing images, and data sources selected in the study include: (i) aerial photograph with a resolution of $100 \mathrm{~m}$ from 1984, (ii) satellite images of Google Earth with a resolution of $15 \mathrm{~m}$ from 1998, and (iii) high-resolution satellite images of Google Earth with a resolution of 2 m from 2012 and 2020. ArcMap 10.2 software was used to perform geometric rectification, coordinate registration, visual interpretation, image vectorization, while verification and correction of obtained data can be performed by field investigation. Further, ArcScene 10.2 was used to create a three-dimensional land use map through overlapping vector land use data and Digital Elevation Model data, which can clearly show the land use evolution in hilly areas. Image interpretation from 1984 and 1998 was combined with the participation of the villagers due to the poor quality of images. Based on the criteria for classifying land use in China and the actual land use characteristics in the study area, land use types were divided into thirteen second-class types, including check dam land, terraces, sloping fields, abandoned fields, forests, shrub land, grassland, industrial and mining land, hydraulic land, rural residential land, rural roads, water and bare land, which were merged in four one-class types, including ecological land, croplands, construction land, and bare land (Table 1). 
Table 1. Classification of land use types of the study area.

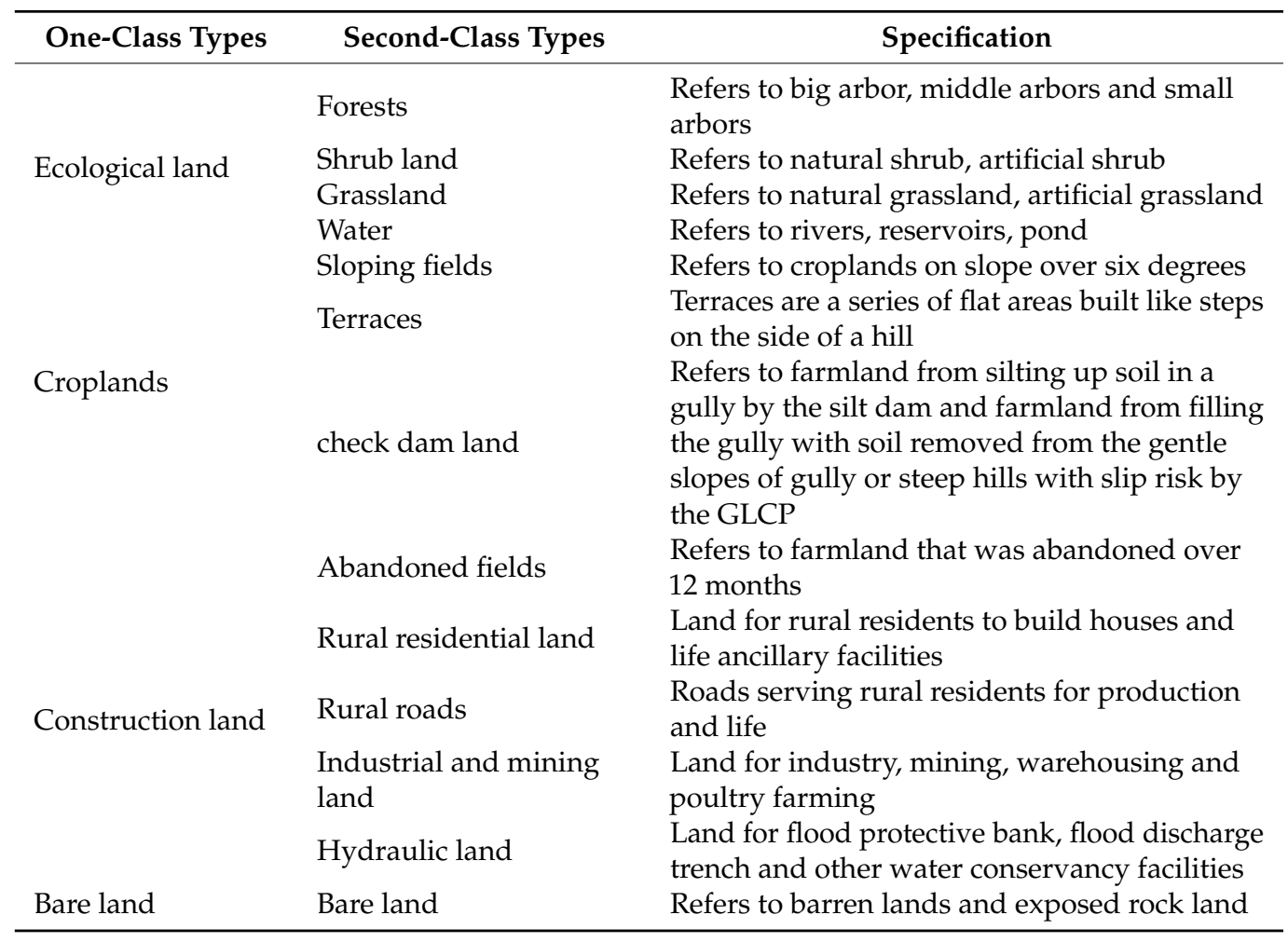

\subsubsection{Estimation of the Relative Altitude of Croplands}

Digital Elevation Model (DEM) data were obtained from the website of Geospatial Data Cloud in China (http:/ / www.gscloud.cn/ (accessed on 31 July 2021)), with a spatial resolution of $30 \mathrm{~m}$. The Raster to Point tool of ArcMap 10.2 was used to extract the elevation of the center point of each grid in DEM data. Then, the ArcMap 10.2 spatial analysis tool was used to assign land class attributes to each point with elevation value, by connecting the point date with vector land use data. Then, the average altitude of each type of cropland will be calculated. The difference between the average altitude of cropland and the average altitude of gully was considered as the relative altitude of each type of cropland. The check dam land is located in the gully, so the relative altitude of the check dam land is considered as zero.

\subsubsection{Land-Use Degree Index}

Land-use degree was used to analyze the extent of land use. It can not only quantitatively reveal the natural properties of land, but also reflect the interaction between human activities and the natural environment [54]. Based on a comprehensive method of land-use degree analysis developed by Prof. Liu Jiyuan et al. [55], the land-use degree is divided into four degrees depending on the stable condition of the land affected by nature and human society, and given a grading index (Table 2). Comprehensive quantified indices of land-use degree are derived from mathematical synthesis of these four degrees and the formula is as follows:

$$
L a=100 \times \sum_{i=1}^{n} P i \times Q i
$$

where, $L a$ is a comprehensive quantified index of land-use degree (LUDI), $P i$ is the grading index of $i$ land-use degree and $Q i$ is the percentage of area of $i$ land-use degree. 
Table 2. The standard of dividing land use degree.

\begin{tabular}{ccccc}
\hline Items & $\begin{array}{c}\text { Unused } \\
\text { Land }\end{array}$ & $\begin{array}{c}\text { Natural } \\
\text { Regeneration Land }\end{array}$ & $\begin{array}{c}\text { Artificial } \\
\text { Regeneration Land }\end{array}$ & $\begin{array}{c}\text { Rural-Urban } \\
\text { Construction Land }\end{array}$ \\
\hline Degree index & 1 & 2 & 3 & $\begin{array}{c}4 \\
\text { hydraulic land, } \\
\text { Land-use } \\
\text { pattern }\end{array}$ \\
bare land & $\begin{array}{c}\text { forests, shrub land, } \\
\text { grassland, water, } \\
\text { abandoned fields }\end{array}$ & $\begin{array}{c}\text { check dam land, } \\
\text { terraces, sloping fields }\end{array}$ & $\begin{array}{c}\text { industrial and mining } \\
\text { land, rural roads, rural } \\
\text { residential land }\end{array}$ \\
\hline
\end{tabular}

\subsubsection{Data Sources and Quantitative Analysis of the Sense of Place}

Data on the sense of place were collected by a questionnaire survey. The questionnaire included basic information about the respondents, PI, PD and PA, and each dimension of the sense of place included different variables. A 5-point Likert scale was applied to quantify the sense of place. For each variable, 5 meanings were used as follows: 5 means "strongly approve", 4 means "approve", 3 means "neutral" attitude, 2 means "disapprove" and 1 means "strongly disapprove". Each variable was scored by the respondents. We conducted a questionnaire survey lasting three days from 30 April to 2 May 2018, while a change in the intensity of the sense of place before 2018 was taken. However, due to the impact of COVID-19, data in 2020 were obtained through online questionnaire and telephone interviews. The average time required to complete each questionnaire was about $1 \mathrm{~h}$. A total of 20 households from Yangjuangou village or the new rural community were selected for the questionnaire survey. Due to the similarity of sense of place among family members, one respondent was involved in each household. Eventually, 20 valid questionnaires were collected. The respondents selected in this study were older than 40 years, so they can provide a clear picture of the development of the catchment in the past 30 years. Moreover, in the process of analysis, we confirmed the information with village cadres and villagers over the telephone many times to ensure the accuracy and reliability of the data.

Data from the questionnaire survey were assessed for reliability. The Cronbach's $\alpha$ value was applied to evaluate the reliability of the data by SPSS 22.0 statistic package, with the higher value representing the better reliability. If the value is greater than 0.7 , the data reliability is good. The test showed that four variables reduced the overall reliability of the scale, namely the identity degree of local culture of PI, neighbors' dependence of PD, growth memory attachment and place rootedness of PA. The standardized Cronbach's value of the three dimensions ranged from 0.708 to 0.950 after the removal of these four variables, suggesting that the reliability of each dimension became good (Table 3 ).

Table 3. The reliability of each dimension of the sense of place.

\begin{tabular}{ccccccccc}
\hline \multirow{2}{*}{ Items } & \multicolumn{4}{c}{ Cronbach's $\alpha$} & \multicolumn{4}{c}{ Standardized Cronbach's $\alpha$} \\
& $\mathbf{2 0 2 0}$ & $\mathbf{2 0 1 2}$ & $\mathbf{1 9 9 8}$ & $\mathbf{1 9 8 4}$ & $\mathbf{2 0 2 0}$ & $\mathbf{2 0 1 2}$ & $\mathbf{1 9 9 8}$ & $\mathbf{1 9 8 4}$ \\
\hline place identity & 0.850 & 0.842 & 0.789 & 0.706 & 0.847 & 0.846 & 0.789 & 0.708 \\
place dependence & 0.939 & 0.837 & 0.715 & 0.720 & 0.942 & 0.851 & 0.726 & 0.730 \\
place attachment & 0.941 & 0.903 & 0.830 & 0.817 & 0.950 & 0.912 & 0.833 & 0.852 \\
\hline
\end{tabular}

Finally, each dimension of the sense of place consisted of four variables. PD included dependence on natural resources, land production dependence, living dependence and lifestyle dependence. PA included social attachment, a sense of belonging to the material environment, a sense of familiarity with the material environment, and attachment to the local culture. PI contained the residents' recognition of beautiful natural landscape, agricultural productive conditions, rural infrastructure and standardized rural management system. The arithmetic means of the scores of all variables were calculated as an index of different items of the sense of place. According to the rule of Likert scale, the average values can be divided into three types: (i) the intensity of the sense of place for the respondents was negative (0 2.5), (ii) the intensity of the sense of place for the respondents 
was intermediate $(2.5 \sim 3.5)$ and (iii) the intensity of the sense of place for the respondents was positive (3.5 5).

\section{Results}

\subsection{Land Use Changes}

During the study period, the application of ecological engineering significantly promoted the optimization of land use structures and the improvement of ecological environment in the study area (Figure 2). The change in croplands was the most significant, with a decrease of $83.39 \mathrm{ha}$, and its share in the total area decreased from $46.92 \%$ in 1984 to $15.33 \%$ in 2020. These changes were mainly due to the reduction of sloping fields from $30.92 \%$ in 1984 to less than $0.1 \%$ in 2020 due to the GGP. The growth of ecological land was the largest, with an increase of $81.19 \mathrm{ha}$, and its share in total area increased from $51.27 \%$ in 1984 to $82.02 \%$ in 2020 . Among them, the percentage of forests in the total area increased the most from $11.06 \%$ in 1984 to $66.01 \%$ in 2020 . In addition, the area of construction land increased by $5.45 \mathrm{ha}$, and its share in the total area increased from $0.49 \%$ in 1984 to $2.56 \%$ in 2020. The area of bare land decreased by 3.25 ha. Land use changes were analyzed for different periods (Table 4).

In the CMSC period (1984-1998), the reduction of croplands was the highest with a decrease of $27.60 \mathrm{ha}$, and its share in the total area decreased by $10.45 \%$. Among them, the sloping fields decreased the most by 36.68 ha due to farmers who voluntarily returned the sloping fields to the forests. The area of terraces and check dam land increased by 7.31 ha and 1.77 ha, respectively. The growth of ecological land was the highest, with an increase of $27.02 \mathrm{ha}$, and its share in the total area increased by $10.23 \%$. This was mainly due to the growth of forests, which had an increase of 19.89 ha. The change of construction land and bare land was not particularly significant.

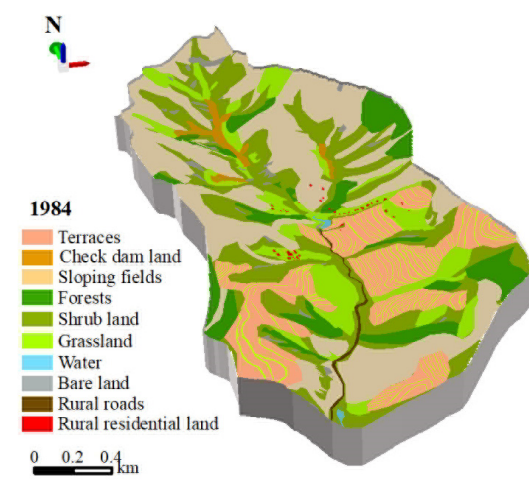

(a)

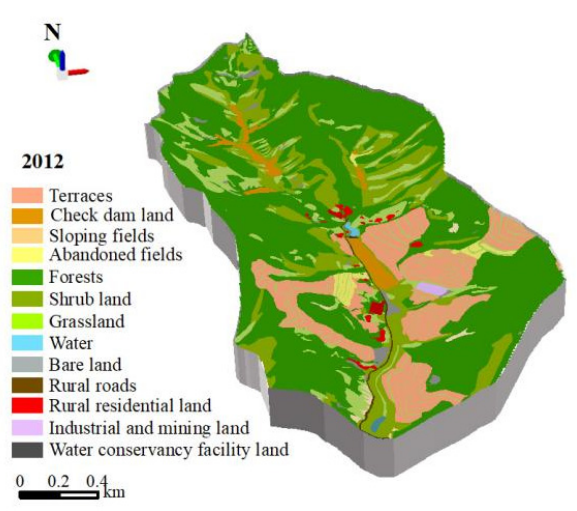

(c)

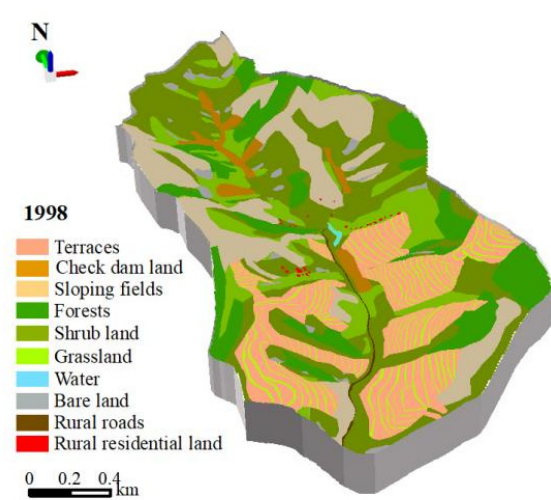

(b)

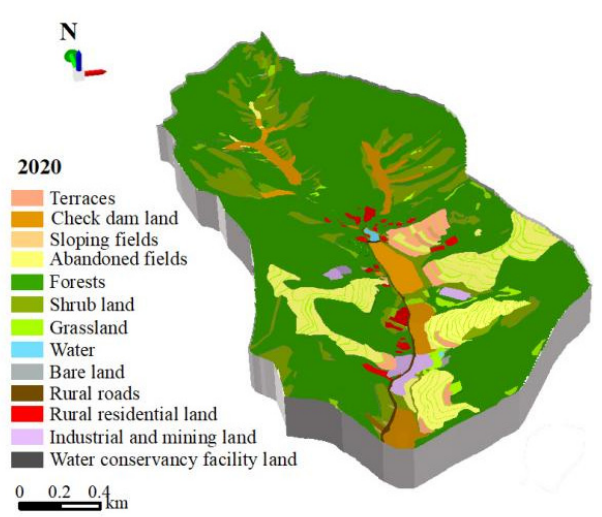

(d)

Figure 2. Land use types of the study area in 1984 (a), 1998 (b), 2012 (c) and 2020 (d). 
Table 4. Area of land use types in the study area from1984 to 2020 (ha).

\begin{tabular}{ccccc}
\hline Types & $\mathbf{1 9 8 4}$ & $\mathbf{1 9 9 8}$ & $\mathbf{2 0 1 2}$ & $\mathbf{2 0 2 0}$ \\
\hline Check dam land & 5.12 & 6.89 & 6.87 & 16.44 \\
Sloping fields & 81.65 & 44.97 & 0.97 & 0.09 \\
Terraces & 37.10 & 44.41 & 29.21 & 5.22 \\
Abandoned fields & - & - & 2.97 & 18.73 \\
Grassland & 36.89 & 42.52 & 25.67 & 8.39 \\
Shrub land & 68.92 & 70.47 & 42.90 & 33.50 \\
Forests & 29.19 & 49.08 & 150.40 & 174.29 \\
Water & 0.37 & 0.32 & 0.42 & 0.38 \\
Rural roads & 1.06 & 0.74 & 0.75 & 0.98 \\
Industrial and mining land & - & - & 0.51 & 3.12 \\
Hydraulic land & - & - & 0.25 & 0.09 \\
Rural residential land & 0.26 & 0.31 & 0.91 & 2.58 \\
Bare land & 3.47 & 4.32 & 2.20 & 0.22 \\
\hline
\end{tabular}

In the GGP period (1998-2012), the reduction of croplands was still the highest with a decrease of $56.25 \mathrm{ha}$, and its share in the total area decreased by $21.30 \%$, mainly due to a significant reduction of sloping fields. The area of sloping fields decreased by 44 ha. The increase in ecological land was still the largest, with an increase of 57 ha, and its share in the total area increased by $21.59 \%$. Therefore, the ecological benefits of the GGP were significant. In addition, the area of bare land reduced by 2.12 ha. The area of construction land increased by 1.37 ha due to the expansion of rural residential and industrial and mining lands, and a chicken farm was constructed on terraces in 2010.

In the GLCP period (2012-2020), the area of ecological land decreased by 2.83 ha, due to the conversion from shrub land and grassland into check dam land, rural residential land and industrial and mining land. However, the forest area increased significantly, with an increase of 23.89 ha. In the same period, croplands increased by 0.46 ha. Among them, the increase in the check dam land area was the largest with an increase of 9.77 ha. For comparison, the reduction of terraces was significant, with a reduction of 8.44 ha, due to the conversion from terraces to shrub land and forests. However, the abandonment of croplands became more frequent and abandoned fields reached 18.73 ha in 2020. In addition, the area of construction land increased by $4.35 \mathrm{ha}$, while the area of rural residential land and industrial and mining land increased by 1.67 ha and 2.61 ha, respectively. At the same time, bare land decreased by 1.98 ha.

\subsection{Characteristics of the Evaluation of Croplands}

In terms of different types of land use, the changes in croplands were the most typical and were reflected in changes in area, structure and spatial distribution. It was noteworthy that the abandonment of croplands in the study area became widespread, and agricultural production became more depressed. The share of crops area in the total area decreased from $46.17 \%$ in 1984 to $8.23 \%$ in 2020 . Moreover, the evolution of croplands is a direct reflection of the sense of place of farmers on the land and is closely linked to sustainable livelihoods of rural residents. Therefore, the evolutionary characteristics of croplands will be analyzed in detail from the aspect of the structure of cropland types, relative altitude and abandonment of croplands (Figure 3).

At the beginning of the study period, the Yangjuangou catchment was characterized by a traditional way of extensive cultivation. The total area of croplands was 123.87 ha, and sloping fields were the main type of croplands, which accounted for $65.92 \%$ of the total area of croplands. The sloping fields were mainly distributed on the top of a hill, slope of a hill, steep slope of a gully and gentle slope of a gully, with an average relative altitude of $66.95 \mathrm{~m}$, which was the highest in investigated period. Secondly, the terraces, with an average relative altitude of $41.13 \mathrm{~m}$, accounted for $29.95 \%$ of the total area of croplands. They were relatively fragmented and mainly located on gentle slope of the gully. The check dam land accounted for only $4.03 \%$ of the total croplands area and was mainly located in the north of the gully. 
Grain yield per unit area of the sloping fields was less than one-third of that of the check dam land, and poor soil and water conservation performance of the sloping fields would affect crop yields. During the CMSC period, farmers spontaneously returned the sloping fields to the forests in 1987 and 1990, which were relatively far from the villages and located on steep slopes of hills and gullies. In addition, the check dam land in the middle of gully was renovated, and the sloping fields at low altitude were turned into terraces. In 1998, the total area of croplands decreased to 96.27 ha, and the sloping fields accounted for $46.71 \%$ of the total croplands. However, sloping fields were still the main type of croplands, and they were mainly distributed on the top of a hill, where the slope is gentle and the soil erosion is not intensive, so the average relative altitude of sloping fields increased by $12.80 \mathrm{~m}$. The percentage of terraces in the total croplands increased to $46.13 \%$, and the average relative altitude of terraces decreased by $7.4 \mathrm{~m}$, because terraces at high altitude were returned to ecological land. The percentage of the check dam land in the total croplands was increased to $7.16 \%$.

With the implementation of the GGP, the total area of croplands was reduced to 40.02 ha in 2012. Terraces have become the main type of croplands, and the percentage of terraces in the total croplands has increased to $72.99 \%$, while the average relative altitude of terraces has decreased by $10.94 \mathrm{~m}$ due to the abandonment of terraces at higher altitude. The proportion of the check dam land in the total croplands has been increased to $17.17 \%$. In contrast, the percentage of sloping fields in the total croplands decreased to $2.42 \%$, the average relative altitude of the sloping fields decreased by $56.99 \mathrm{~m}$, which was lower than the altitude of the terraces and was mostly located on the toe of the slope with low and gentle terrain. Abandonment of croplands occurred in 2012, which accounted for $7.42 \%$ of the total croplands. In particular, the abandoned terraces and the abandoned check dam land accounted for $87.21 \%$ and $12.79 \%$ of the total abandoned fields, respectively.

The GLCP was implemented in 2013 in the study area, so check dam land in the middle of the gully with flat terrain was significantly increased. In addition, the check dam land with poor farming conditions in the northern gully was renovated. In 2020, the total area of croplands increased to 40.48 ha, check dam land became the main type of croplands, and the percentage of the check dam land area in the total croplands area increased to $40.61 \%$. However, the percentage of terraces in the total area of croplands decreased to $12.90 \%$ and its average relative altitude decreased by $12.87 \mathrm{~m}$, due to the fact that some terraces at higher altitude were abandoned. In addition, the percentage of sloping fields in the total croplands decreased to $0.22 \%$, and the average relative altitude decreased by $14.29 \mathrm{~m}$. In the later period of the study, $46.27 \%$ of croplands were abandoned. In particular, the percentage of abandoned terraces in all abandoned fields increased to $96.88 \%$. The sown terraces are wide terraces with good farming conditions and close to the residence. The percentage of abandoned check dam land in the total abandoned fields decreased to $3.11 \%$, which was mainly located in the northern gully far from the residential area.

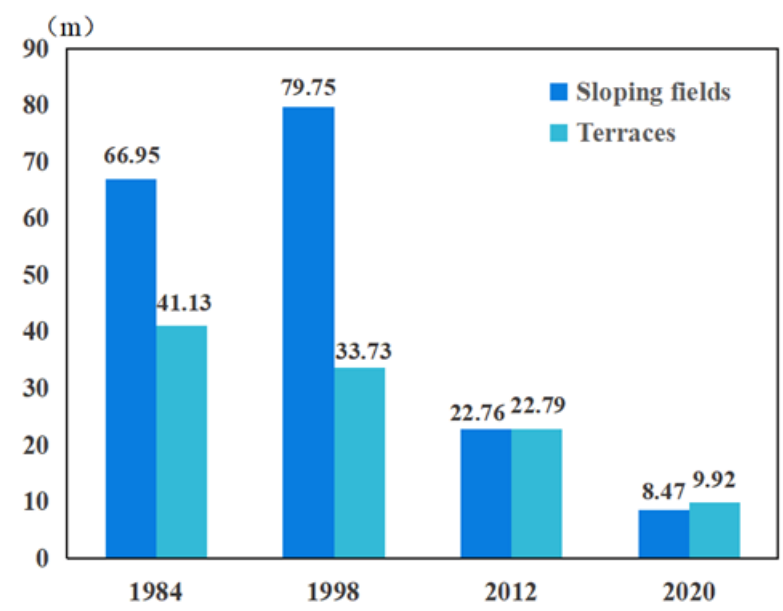

Figure 3. Average relative altitude of croplands from 1984 to 2020. 
In general, guided by ecological restoration strategies, the study area has changed from an extensive cultivation phase to a terrace-dominated cultivation mode, and finally to a cultivation mode dominated by check dam land. In addition, the relative altitude of croplands has decreased. These changes reflected an effective improvement in ecological management and agricultural production conditions in LHGR. However, the abandonment of croplands reflected the change in farmers' livelihood from living on the land to working outside, i.e., the land was no longer the main source of farmers' livelihood.

\subsection{Change of Land Use Degree}

LUDI of Yangjuangou catchment decreased by 30 during the study period, which indicated that the availability of natural land attributes has improved, i.e., the exploitation of land resources has declined (Figure 4). From 1998 to 2012, the rate of decline of LUDI was the fastest, with an average annual decline of 1.43, mainly due to the accelerated reduction of croplands with a higher land use degree under the influence of the GGP. In addition, from 1984 to 1998, LUDI declined rapidly, with an average annual decline of 0.78 , mainly due to the conversion of sloping fields into ecological land under the influence of the CMSC. From 2012 to 2020, LUDI declined slightly, with an average annual decline of 0.25 , indicating that increasing attention was gradually being paid to the rational use of land resources. Although the abandonment of croplands was most severe from 2012 to 2020, the GLCP significantly increased the check dam land area with better production conditions, while rural residential land and industrial and mining land with the highest land use degree has increased due to improved rural infrastructure. Therefore, the rate of decline in land use degree has slowed in this period. Overall, the decline in land use degree was mainly the result of the reduction of croplands due to ecological projects and the abandonment of croplands because of the increased migration of farmers.

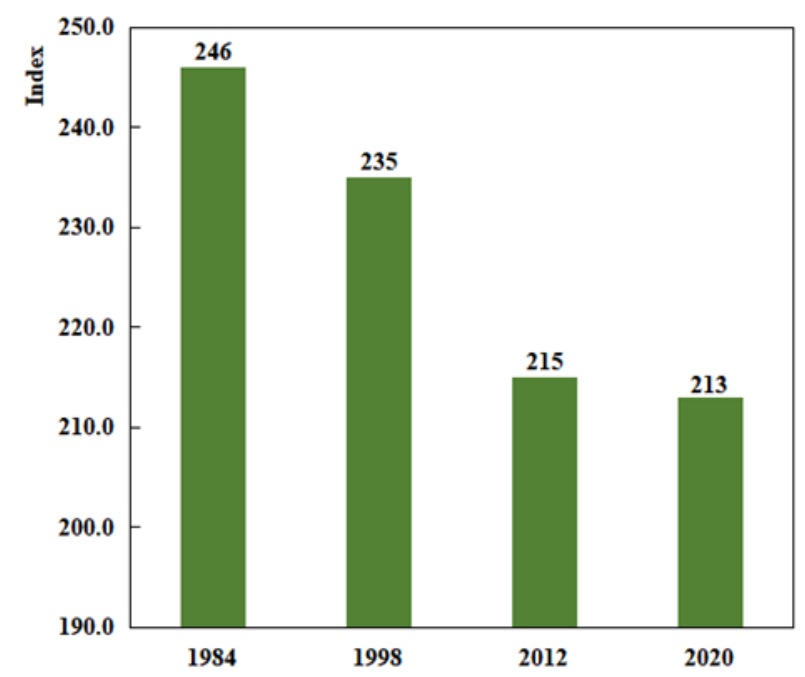

Figure 4. Comprehensive quantified index of land-use degree in the study area from 1984 to 2020.

\subsection{Interpretation of the Change of Sense of Place}

The intensity of the sense of place of local farmers showed a fluctuating declining trend during the study period (Figure 5). From 1984 to 1998, the sense of place index decreased by 0.19 , mainly due to a decrease in PD and PA, which accounted for $77.65 \%$ and $22.35 \%$ of the decrease, respectively. However, the average value of PI increased by 0.28. From 1998 to 2012, the total value of the sense of place increased by 0.04 , mainly due to an increase in the average value of PI, which increased by 1.27. In comparison, the average value of PD and PA decreased by 0.72 and 0.42, respectively. From 2012 to 2020, the decline in the total value of sense of place was the largest with 0.25 . The decrease in PD and PA accounted for $80.15 \%$ and $19.85 \%$ of the decrease in the sense of place, yet the 
average value of PI increased by 0.61 . We provide a detailed analysis of the changes in each dimension of the sense of place in the following subsections.

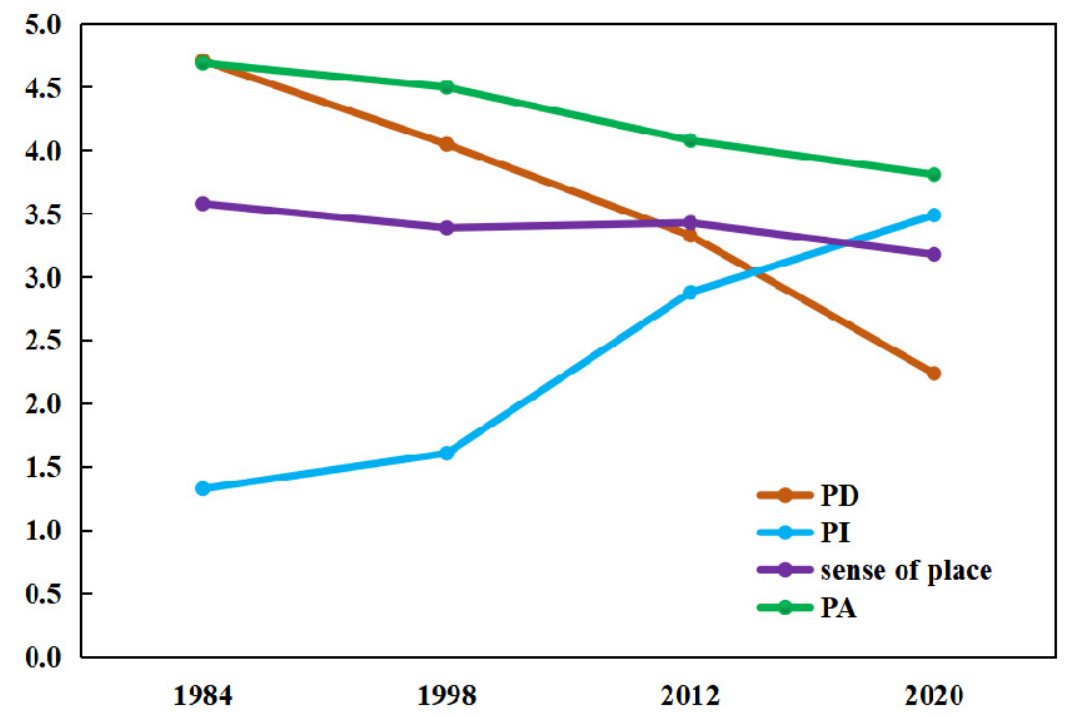

Figure 5. Intensity index of the sense of place of local farmers. PI = Place identity; PD = Place dependence; PA = Place attachment.

\subsubsection{Changes in the Place Dependence Index}

The PD index decreased the most, from 4.71 in 1984 to 2.24 in 2020, which indicated that the intensity of PD of local farmers has changed from positive dependence to negative dependence. Four variables of PD showed a declining trend (Figure 6). Among them was a significant decrease in the indices of natural resources dependence, land production dependence and living dependence, which decreased by 2.86, 2.64 and 2.54, respectively, and changed from positive dependence to negative dependence. However, the index of lifestyle dependence declined slightly and changed from positive dependence to intermediate dependence.

The decline in PD of local farmers was mainly influenced by natural and human factors, such as policy implementation, market economy, and natural disasters. In particular, the GGP banned farmers from exploiting ecological resources, which was one of the key factors in the decline in dependence on natural resources. The decline in land production dependence was influenced not only by ecological projects, but also by market economy factors. On the one hand, ecological projects have promoted the transformation from a large number of sloping fields into ecological land, which has changed the source of livelihood for farmers. On the other hand, rising costs of agricultural production have encouraged an increasing number of rural workers to start working in the non-agricultural production sector, leading to marginalization and abandonment of croplands. In addition, farmers confidence in the development of planting industry has been affected by extreme weather conditions and other natural disasters. Through household interviews, we learned that almost all crops on terraces were destroyed in 2013 due to extreme rainstorms, so many farmers decided to migrate. Moreover, the number of wild animals has increased due to ecological restoration, which has a negative impact on the crops on the terraces, leading to more rural residents deciding to abandon the terraces. The widespread abandonment of croplands was the visual response of the decline in land production dependence. Decline in living dependence was affected by rural labor migration and the Village Combination Project in 2013. The index of lifestyle dependence decreased, as farmers gradually adopted a new concept of life, with rural inhabitants going out to work and moving to cities and towns. 


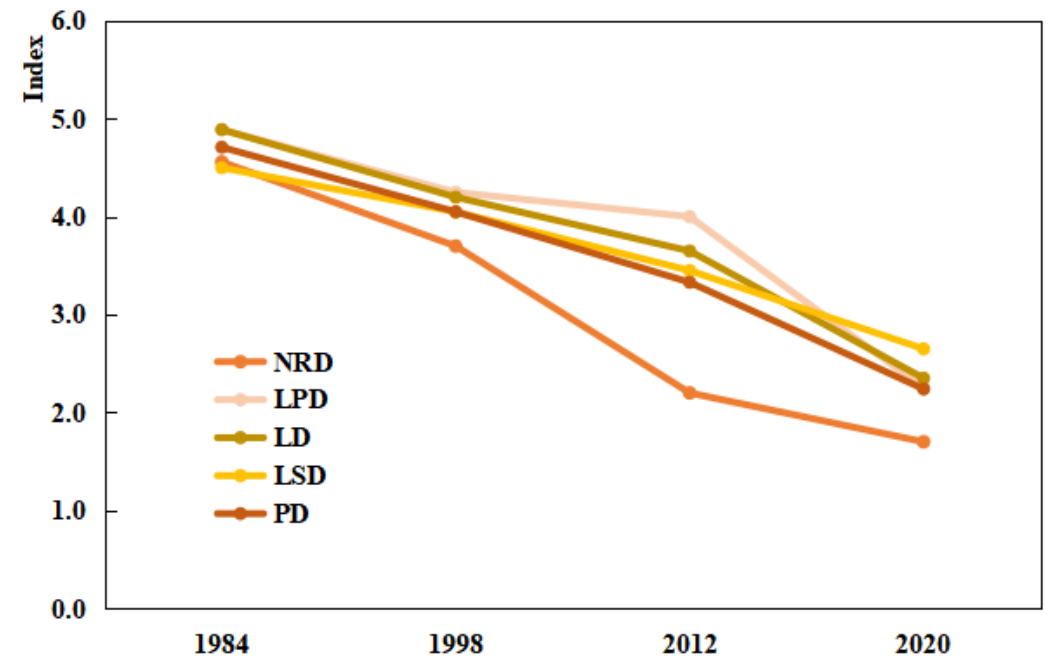

Figure 6. Intensity index of the place dependence of local farmers. NRD = Natural resources dependence; $\mathrm{LPD}=$ Land production dependence; $\mathrm{LD}=$ Living dependence; $\mathrm{LSD}=$ Lifestyle dependence; $\mathrm{PD}=$ Place dependence.

\subsubsection{Changes in the Place Attachment Index}

The PA index decreased from 4.69 in 1984 to 3.81 in 2020, and its intensity remained positive. Four variables of PA decreased and among them, the value of the index of social attachment decreased the most (Figure 7). Then, the sense of belonging to the material environment and the sense of familiarity with the material environment decreased by 0.97 and 0.94 , respectively. The index of attachment to the local culture decreased by only 0.44 . The intensity of the other three variables was positive, except that the intensity of the sense of belonging to the material environment has changed from positive to intermediate.

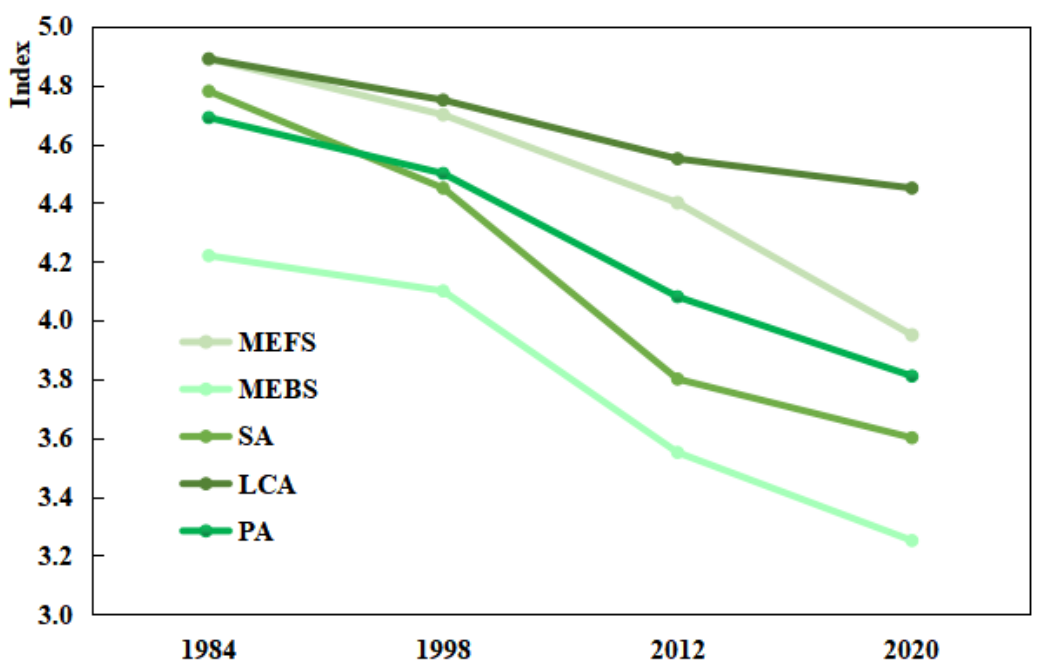

Figure 7. Intensity index of the place attachment of local farmers. MEFS = The sense of familiarity with the material environment; MEBS = The sense of belonging to the material environment; $\mathrm{SA}=$ Social attachment; LCA = Attachment to the local culture; PA = Place attachment.

The change in PA reflected the contradiction of psychological changes of farmers. On the one hand, if farmers have certain abilities or life pressure, they decide to engage in the non-agricultural industries with higher incomes. On the other hand, the land is still very important for the rural residents, as it is the ultimate guarantee for farmers' livelihood. According to the field investigation, local farmers believed that when they are too old and could not to go out to work, they still wanted to rely on the land to survive. This is in line 
with the Chinese cultural tradition of attachment to the homeland, i.e., although farmers are busy working far from home, they still have a strong topophilia. Therefore, although the intensity of PA of local farmers decreased, it was still positive.

\subsubsection{Changes in the Place Identity Index}

The PI index increased from 1.33 in 1984 to 3.49 in 2020, indicating that the PI intensity of farmers changed from negative to intermediate. Four variables of PI increased (Figure 8). Among them, the residents' recognition of beautiful natural landscape and agricultural productive conditions increased by 2.76 and 2.48 , respectively. The residents' recognition of rural infrastructure and standardized rural management system increased by 1.83 and 1.54 , respectively. The intensity of all variables changed from negative to intermediate.

The improvement in PI intensity was mainly the result of the promotion of ecological projects. The increase in the residents' recognition of beautiful natural landscape has been the most significant since 1998. It can be seen that the GGP has an obvious positive effect on ecological restoration and farmers have unanimously recognized it. In addition, the agricultural production conditions of the catchment have been significantly improved. In particular, the GLCP has significantly promoted the growth of the check dam land with high-yield, so the rate of increase in the residents' recognition of agricultural production conditions was the highest from 2012 to 2020. Moreover, with social progress and increased government investment in rural construction, the residents' recognition of rural infrastructure and the standardized rural management system has improved, but had intermediate value at the end of the study period and still needs to be improved.

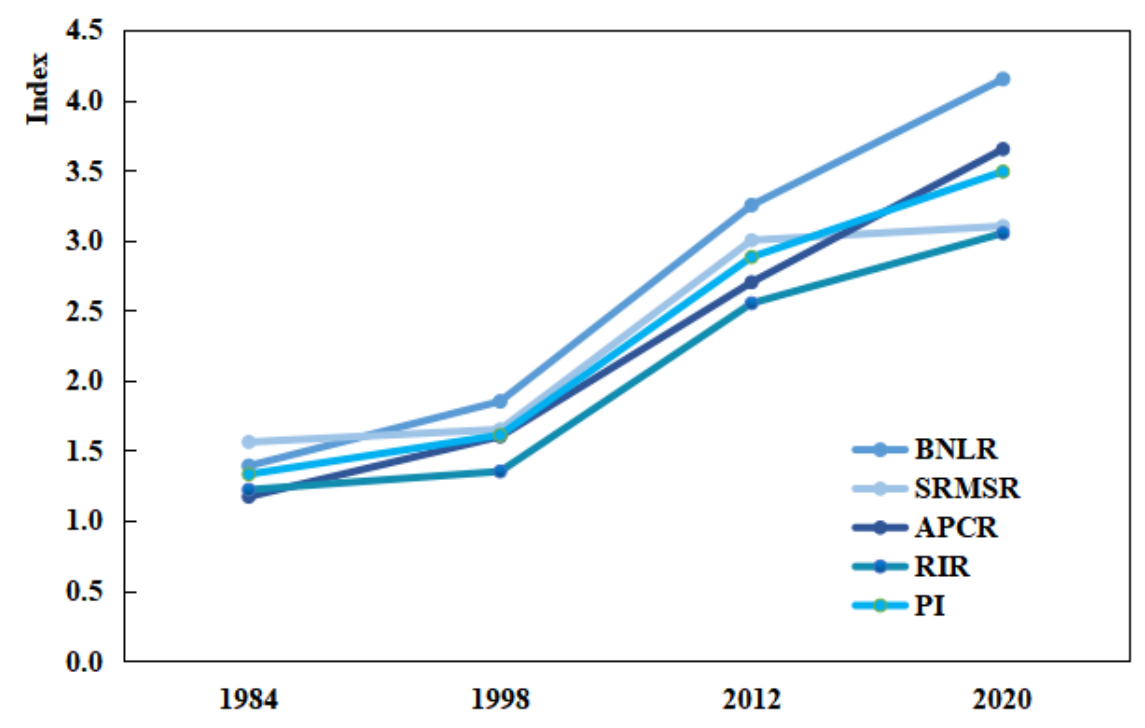

Figure 8. Intensity index of the place identity of local farmers. BNLR $=$ The recognition of residents on beautiful natural landscape; SRMSR = The recognition of residents on standardized rural management system; APCR = The recognition of residents on agricultural productive conditions; RIR = The recognition of residents on rural infrastructure; PI = Place identity.

\section{Interaction between Land Use and the Sense of Place of Farmers}

The sense of place of farmers is an inherent expression of the relationship between humans and environment in traditional society [56-58]. There is an interaction between farmers' sense of place and land use (Figure 9), which we have qualitatively evaluated based on a quantitative change in the sense of place and land use.

As a living space, the change of land in the relationship between humans and environment is dominated by a change in the sense of place of humanity [50]. Prior to the 1980s, livelihoods of the rural residents were tied to a land and characterized by subsistence agriculture. Therefore, the main land use patterns in the study area had long been sloping fields influenced by the strong intensity of PD and PA of local farmers. Then, the intensity 
of PD and PA of local farmers gradually decreased due to the deterioration of the natural environment and low comparative benefit of agricultural production, which promoted the conversion of sloping fields to ecological land in the period of the CMSC. During the GGP period, PD and PA of local farmers further declined due to the GGP financial subsidies aimed at converting more sloping fields into forests. In addition, natural disasters have accelerated the reduction of PD and PA of local farmers. The confidence of local farmers in the development of agriculture has been undermined by natural disasters, and an increasing number of rural workers decided to migrate, leading to the abandonment of check dam land and terraces with poor production conditions. Moreover, the Village Combination Project also led to the decline of PD and PA of local farmers, and more croplands were abandoned. In the end, the terraces with better cultivation conditions were abandoned.

Under the influence of land use changes, farmers reconsider the land, which affects the sense of place of farmers. Ecological and livelihood projects have increased the land use proportion of check dam land, ecological land, roads and other infrastructure and optimized the land use structure. Conclusively, the PI intensity of local farmers has obviously improved. At the same time, the premise of increasing the ecological land was to give up more opportunities of agricultural production, which led to a decrease in the intensity of PA and PD of local farmers. It is notable that, although the area of the check dam land with high yield increased, which accounted for only $6.23 \%$ of the study area, farmers were not enthusiastic about traditional agriculture due to limited area for farming, which has no significant impact on rural development, and the residents' recognition of agricultural production conditions has yet to be further improved.

In LHGR, the decline in land use degree has revealed a decline in farmers' dependence on the production and living functions of land and a weakening of farmers' attachment to rural areas to a certain extent. In general, with the decline in land use degree, the sense of place of farmers also showed a declining trend. It showed that farmers are not traditional farmers and land is no longer the only material dependence of farmers, as farmers' livelihood patterns have become diverse, and rural areas are in the process of transformation from traditional agricultural stage to non-agricultural stage.

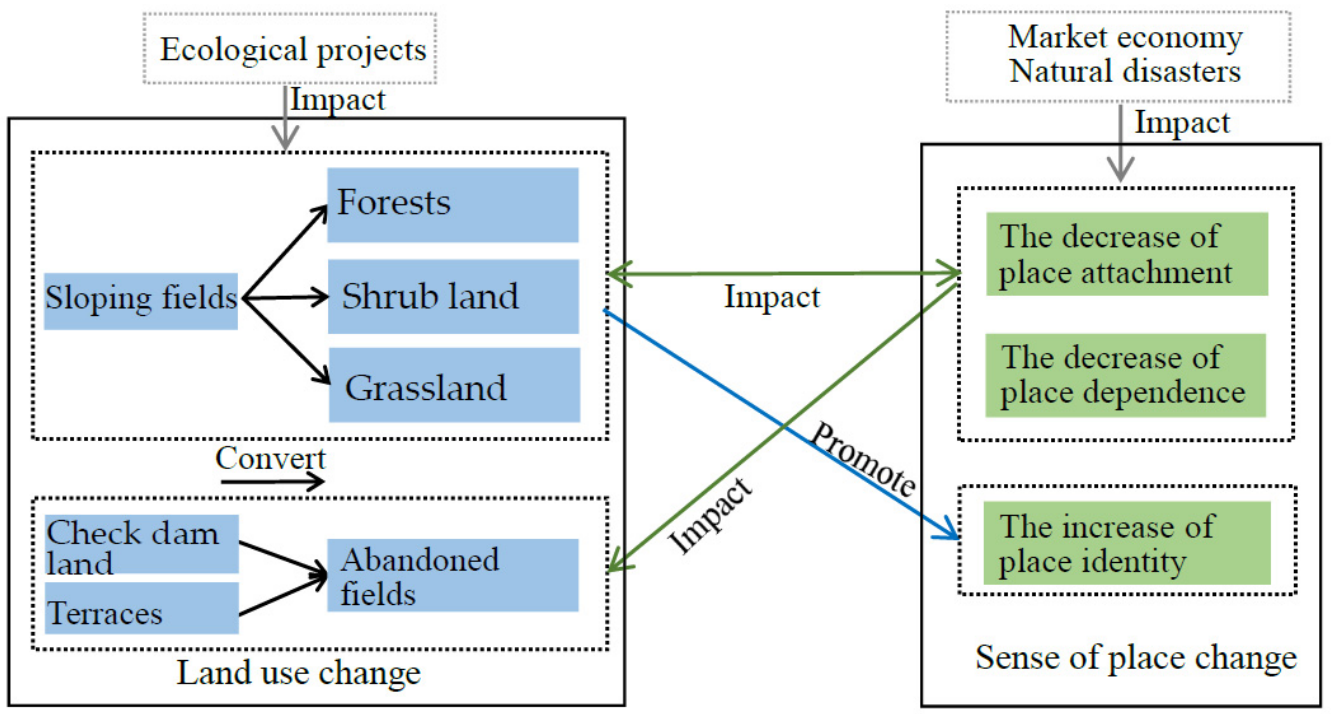

Figure 9. The interaction between land use and sense of place in the study area.

\section{Discussion}

This paper comprehensively explored land use changes and farmers' sense of place and the interaction between them, with the implementation of ecological and livelihood projects in a typical small catchment in LHGR from 1984 to 2020. The study of land use changes mainly involved the change in ecological land, construction land, croplands and bare land. The change in croplands was the most significant and is closely related to the 
change in the sense of place of farmers. Therefore, the evolution of croplands was analyzed in detail from the aspect of structure, relative altitude and abandonment of croplands. Then, the land use degree in the study area was quantitatively analyzed. In addition, the farmers' sense of place was quantitatively analyzed from the perspective of PI, PD and PA. That is, it was studied from following aspects: farmers' recognition of production and living functions of land, farmers' recognition of natural and human environment, and the emotional connection between farmers and land. Furthermore, the interactive mechanism between land use and the sense of place of farmers was explored. It is noticeable that there has been a lot of research on land use changes in LHGR, and it was mostly concentrated on the process of land use change and its ecological benefits at the county and regional level, and was rarely related to the sense of place of farmers at the village level [58-60]. Therefore, the influence of human subjectivity on land use change has been ignored. The novelty of this paper was that not only the land use changes from the micro level of the small catchment were explored, but also the interaction between the land use changes and the sense of place of farmers was explored in detail, which was helpful for people to deeply understand the evolution of rural space from a perspective of residents' cognition and provided a scientific reference for the construction of a highly satisfactory rural settlement. We will further discuss the implications derived from the above study.

\subsection{Innovating Land Use Patterns and Improving the Efficiency of Resource Utilization}

From the case study of this paper, although PI of farmers increased through the implementation of ecological and livelihood projects, PD and PA of farmers have decreased significantly. These changes were mainly manifested in a significant decline in the LUDI. For example, the abandonment of croplands in the study area was widespread, and almost $30 \%$ of croplands were abandoned. It can be seen that, although the implementation of different ecological projects has significantly improved the ecological environment and rural infrastructure, most of the land resources were still idle. That is, the socio-economic system has not yet adapted to the evolution of the geographic environment system in the catchment and there are still possibilities for optimizing the land use structure. According to research by Li et al., the function of ecosystem services has increased significantly on the Loess Plateau, but farmers could only benefit from the construction and management of ecological resources through ecological compensation. Moreover, due to the virtual property rights, unreasonable industrial structure, and imperfect land market mechanisms, the development of rural industries related to the exploitation of natural resources has lagged behind. As a result, a large number of rural workers turned to migrant workers, which led to extensive management and abandonment of croplands [36]. Lyu Changhe et al. believed that crop sown area decreased by $5 \%$ on the whole plateau and by $10 \%$ in the hilly region during 1998-2014 [61]. Our research was in line with the findings of previous research, i.e., low efficiency of the utilization of natural resources is a common problem in rural areas of the Loess Plateau. It will therefore be of great significance for the rural vitalization of LHGR to deeply explore innovative land use patterns to consider optimal land use as a key activity, to consider land engineering and rural land circulation as means, and to consider high agricultural efficiency as a breakthrough, to revitalize the idle land.

\subsection{Diversification of Farmers' Livelihoods to Ensure Their Sustainability}

With the implementation of the Cropland Reconversion Program, the Development of West China, and the Urbanization Development Strategy of China, the number of migrant workers from rural areas in LHGR has increased. However, due to the low level of education of farmers, most migrant workers are engaged in low-tech low-wage jobs, and the potential for increasing their incomes is limited [62]. There are great challenges in the sustainability of farmers' livelihoods in LHGR. The difference between farmers in the Yangjuangou catchment was obvious in terms of agricultural production mode, livelihood capital allocation and risk coping ability. Specifically, $21.87 \%$ of farmers were engaged in agricultural production, $57.66 \%$ of farmers were migrant workers and $14.60 \%$ 
of farmers were engaged in non-farm self-employment. Regarding the future livelihood plan of farmers, $70 \%$ of them want to adjust the cropping structure and expand the scope of planting crops; $60 \%$ of farmers who rely on non-agricultural income believe that they still need land to make a living when they are older and not recognized by the society; and $40 \%$ of farmers living in new rural communities want to rebuild their households, mainly because they cannot afford to buy a new house in the cities. This showed that the current livelihood mode of most farmers has not reached the expected standard of living or they have a better and more stable livelihood mode to choose from, and the land remains a strong guarantee of the security of farmers' livelihoods. Therefore, the overall value of the sense of place of local farmers was still higher. The instability of farmers' livelihoods has become one of the key problems limiting the sustainable development of LHGR. In the LHGR, on the one hand, governments should help farmers build an efficient social capital network by expanding employment channels to diversify farmers' sources of income, as well as improve the cultural level and professional skills of farmers in order to improve their adaptability and anti-risk capacity for the market economy. On the other hand, the agricultural structure of planting should be optimized and adjusted in order to stimulate farmers' enthusiasm for agricultural production and promote rural development. For example, the authorities need to pay more attention to specialty and branded agricultural products, moreover, the added value of agricultural products needs to be improved.

\section{Conclusions}

This paper investigated the change and interaction of land use and the sense of place of farmers in a typical watershed of LHGR from 1984 to 2020, based on high-resolution remote sensing image data, GIS technique and household surveys. The main results were as follows: (1) the changes in ecological land and croplands were the most significant. The area of ecological land increased significantly, and the growth of forests was the highest. On the contrary, the area of croplands has decreased significantly, especially the sloping fields, and the abandonment of terraces has become more frequent. However, the area of the check dam land increased with the promotion of the GLCP. Generally speaking, the land use degree has been gradually declining; (2) the total value of the sense of place of local farmers showed a fluctuating downward trend. In particular, PD and PA showed a downward trend, the former declining the most, while PI increased; and (3) the land use change was dominated by the sense of place of farmers, while the land use change influenced the adjustment of the sense of place of farmers as it led the farmers to reconsider the land. This paper suggested that the rural areas in LHGR should innovate land use patterns and promote high efficiency and intensification of agriculture through land engineering and rural land circulation. Moreover, while ensuring the effects of ecological restoration, the government should also pay attention to extending livelihood strategies and improving the adaptability and anti-risk capability of farmers to a market economy, in order to promote the harmonious development of human-environmental relations in LHGR.

This paper was a preliminary study on the links between land use change and the farmers' sense of place in rural areas of the LHGR, and further research is needed. Firstly, due to the limitations of remote sensing images and data acquisition, only a typical catchment was selected in this study, and a comparative study of multiple catchments should be further conducted to fully understand the human-environment relationship in LHGR. Secondly, the theoretical framework of the interaction between land use and the sense of place of farmers, i.e., the dynamic concept of interaction between humans and environment needs to be improved with more examples. In addition, the research objects selected in this study were middle-aged and older population, so attention should be paid to the sense of place of farmers of different ages.

Author Contributions: Conceptualization, Y.L. (Yi Li), Y.L. (Yurui Li) and B.F.; methodology, Y.L. (Yi Li); software, Y.L. (Yi Li); validation, Y.L. (Yi Li), Y.L. (Yurui Li) and B.F.; formal analysis, Y.L. (Yi Li); investigation, Y.L. (Yi Li), C.W. and W.L.; resources, Y.L. (Yi Li); data curation, Y.L. (Yi Li) and Y.L. (Yurui Li); writing—original draft preparation, Y.L. (Yi Li); writing—review and editing, Y.L. (Yurui 
Li), B.F. and L.Q.; visualization, Y.L. (Yi Li), Y.L. (Yurui Li) and B.F.; supervision, Y.L. (Yurui Li) and B.F.; project administration, Y.L. (Yi Li); funding acquisition, Y.L. (Yurui Li). All authors have read and agreed to the published version of the manuscript.

Funding: This research was funded by the National Key Research and Development Program of China, grant number 2017YFC0504701 and the National Natural Science Foundation of China, grant number 41271189, 41671174).

Data Availability Statement: The Sources and preprocessing of data are in Section 2.3. Other relevant data to support this study are available from the authors upon request.

Acknowledgments: The authors would like to thank the anonymous reviewers for their comments and suggestions which contributed to the further improvement of this paper.

Conflicts of Interest: The authors declare no conflict of interest.

\section{References}

1. Cao, Z.; Li, Y.; Liu, Z.; Yang, L. Quantifying the vertical distribution pattern of land-use conversion in the loess hilly region of northern Shaanxi Province 1995-2015. J. Geogr. Sci. 2019, 29, 730-748. [CrossRef]

2. Liu, Y.; Guo, Y.; Li, Y.; Li, Y. GIS-based effect assessment of soil erosion before and after gully land consolidation: A case study of Wangjiagou project region, Loess Plateau. Chin. Geogr. Sci. 2015, 25, 137-146. [CrossRef]

3. McVicar, T.R.; Li, L.; Van Niel, T.; Zhang, L.; Li, R.; Yang, Q.; Zhang, X.; Mu, X.; Wen, Z.; Liu, W.; et al. Developing a decision support tool for China's re-vegetation program: Simulating regional impacts of afforestation on average annual streamflow in the Loess Plateau. For. Ecol. Manag. 2007, 251, 65-81. [CrossRef]

4. Liu, Y.S.; Li, Y.R. Engineering philosophy and design scheme of gully land consolidation in Loess Plateau. Trans. CSAE 2017, 33, 1-9. [CrossRef]

5. Cao, Z.; Li, Y.R.; Liu, Y.S.; Chen, Y.; Wang, Y. When and where did the Loess Plateau turn "green" Analysis of the tendency and breakpoints of normalized difference vegetation index. Land Degrad. Dev. 2017, 29, 1085-3278. [CrossRef]

6. Fu, B.; Liu, Y.; Lü, Y.; He, C.; Zeng, Y.; Wu, B. Assessing the soil erosion control service of ecosystems change in the Loess Plateau of China. Ecol. Complex. 2011, 8, 284-293. [CrossRef]

7. Li, Y.; Li, Y.; Fan, P.; Sun, J.; Liu, Y. Land use and landscape change driven by gully land consolidation project: A case study of a typical watershed in the Loess Plateau. J. Geogr. Sci. 2019, 29, 719-729. [CrossRef]

8. Jiang, N.; Shao, M.A. Characteristics of Soil and Water Loss of Different Slope Land Uses in Small Watershed on the Loess Plateau. Trans. CSAE 2011, 27, 36-41. [CrossRef]

9. Lu, X.-L.; Wu, C.-Y.; Xiao, G.-R. Fuzzy synthetic evaluation on resident's perceptions of tourism impacts. Chin. Geogr. Sci. 2006, 16, 87-94. [CrossRef]

10. Zhou, Q.H. Settlements in the Valley of the Loess Plateau; China Architecture \& Building Press: Beijing, China, 2009.

11. Li, Y.R.; Li, Y.; Fan, P.C.; Liu, Y.S. Impacts of Land Consolidation on Rural Human-environment System in Typical Watershed of Loess Hilly and Gully Region. Trans. CSAE 2019, 35, 241-250. [CrossRef]

12. Liu, G.B.; Yang, Q.K.; Zheng, F.L. Small Watershed Management and Eco-rehabilitation on the Loess Plateau of China. Sci. Soil Water Conserv. 2004, 2, 11-15.

13. Perring, M.; De Frenne, P.; Baeten, L.; Maes, S.L.; Depauw, L.; Blondeel, H.; Carón, M.M.; Verheyen, K. Global environmental change effects on ecosystems: The importance of land-use legacies. Glob. Chang. Biol. 2016, 22, 1361-1371. [CrossRef]

14. Güneralp, B.; Seto, K.C.; Ramachandran, M. Evidence of urban land teleconnections and impacts on hinterlands. Curr. Opin. Environ. Sustain. 2013, 5, 445-451. [CrossRef]

15. Shi, P.J.; Gong, P.; Li, X.B. Research Method and Practice of Land Use/Land Cover; Science Press: Beijing, China, 2000.

16. Liu, Y.S. Introduction to land use and rural sustainability in China. Land Use Policy 2018, 74, 1-4. [CrossRef]

17. Skokanová, H.; Havlíček, M.; Borovec, R.; Demek, J.; Eremiášová, R.; Chrudina, Z.; Mackovčin, P.; Rysková, R.; Slavík, P.; Stránská, T.; et al. Development of land use and main land use change processes in the period 1836-2006: Case study in the Czech Republic. J. Maps 2012, 8, 88-96. [CrossRef]

18. Betts, R. Implications of land ecosystem-atmosphere interactions for strategies for climate change adaptation and mitigation. Tellus B Chem. Phys. Meteorol. 2007, 59, 602-615. [CrossRef]

19. Long, H.; Qu, Y. Land use transitions and land management: A mutual feedback perspective. Land Use Policy 2018, 74, 111-120. [CrossRef]

20. Bazame, R.; Tanrivermis, H.; Kapusuz, Y.E. Land management and sustainable use of land resources in the case of Burkina Faso. Land Degrad. Dev. 2019, 30, 608-621. [CrossRef]

21. Mottet, A.; Ladet, S.; Coqué, N.; Gibon, A. Agricultural land-use change and its drivers in mountain landscapes: A case study in the Pyrenees. Agric. Ecosyst. Environ. 2006, 114, 296-310. [CrossRef]

22. Wang, J.; Chen, Y.; Shao, X.; Zhang, Y.; Cao, Y. Land-use changes and policy dimension driving forces in China: Present, trend and future. Land Use Policy 2012, 29,737-749. [CrossRef] 
23. Li, Y.; Cao, Z.; Long, H.; Liu, Y.; Li, W. Dynamic analysis of ecological environment combined with land cover and NDVI changes and implications for sustainable urban-rural development: The case of Mu Us Sandy Land, China. J. Clean. Prod. 2017, 142, 697-715. [CrossRef]

24. Halmy, M.W.A.; Gessler, P.E.; Hicke, J.A.; Salem, B. Land use/land cover change detection and prediction in the north-western coastal desert of Egypt using Markov-CA. Appl. Geogr. 2015, 63, 101-112. [CrossRef]

25. Song, X.-P.; Hansen, M.C.; Stehman, S.V.; Potapov, P.V.; Tyukavina, A.; Vermote, E.F.; Townshend, J.R. Global land change from 1982 to 2016. Nature 2018, 560, 639-643. [CrossRef] [PubMed]

26. Dadashpoor, H.; Azizi, P.; Moghadasi, M. Land use change, urbanization, and change in landscape pattern in a metropolitan area. Sci. Total Environ. 2019, 655, 707-719. [CrossRef]

27. Chu, H.; Lin, Y.-P.; Huang, C.-W.; Hsu, C.-Y.; Chen, H.-Y. Modelling the hydrologic effects of dynamic land-use change using a distributed hydrologic model and a spatial land-use allocation model. Hydrol. Process. 2010, 24, 2538-2554. [CrossRef]

28. Dirmeyer, P.; Niyogi, D.; De Noblet-Ducoudré, N.; Dickinson, R.E.; Snyder, P.K. Impacts of land use change on climate. Int. J. Clim. 2010, 30, 1905-1907. [CrossRef]

29. Sharma, G.; Sharma, L.; Sharma, K.C. Assessment of land use change and its effect on soil carbon stock using multitemporal satellite data in semiarid region of Rajasthan, India. Ecol. Process. 2019, 8, 42. [CrossRef]

30. Foley, J.A.; DeFries, R.; Asner, G.P.; Barford, C.; Bonan, G.; Carpenter, S.R.; Chapin, F.S.; Coe, M.T.; Daily, G.C.; Gibbs, H.K.; et al. Global Consequences of Land Use. Science 2005, 309, 570-574. [CrossRef]

31. Guerra, C.A.; Rosa, I.M.D.; Pereira, H.M. Change versus stability: Are protected areas particularly pressured by global land cover change? Landsc. Ecol. 2019, 34, 2779-2790. [CrossRef]

32. Levine, N.S.; Kaufman, C.C. Land Use, Erosion, and Habitat Mapping on an Atlantic Barrier Island, Sullivan's Island, South Carolina. J. Maps 2008, 4, 161-174. [CrossRef]

33. Shi, H.; Shao, M. Soil and water loss from the Loess Plateau in China. J. Arid. Environ. 2000, 45, 9-20. [CrossRef]

34. Fu, B.; Chen, L.; Ma, K.; Zhou, H.; Wang, J. The relationships between land use and soil conditions in the hilly area of the loess plateau in northern Shaanxi, China. Catena 2000, 39, 69-78. [CrossRef]

35. Cao, Z.; Liu, Y.; Li, Y. Rural transition in the loess hilly and gully region: From the perspective of "flowing" cropland. J. Rural. Stud. 2019. [CrossRef]

36. Li, Y.; Zhang, X.; Cao, Z.; Liu, Z.; Lu, Z.; Liu, Y. Towards the progress of ecological restoration and economic development in China's Loess Plateau and strategy for more sustainable development. Sci. Total Environ. 2021, 756, 143676. [CrossRef]

37. Davenport, M.A.; Anderson, D.H. Getting From Sense of Place to Place-Based Management: An Interpretive Investigation of Place Meanings and Perceptions of Landscape Change. Soc. Nat. Resour. 2005, 18, 625-641. [CrossRef]

38. Johnston, R.J. The Dictionary of Human Geography; The Commercial Press: Beijing, China, 2004.

39. Jorgensen, B.S.; Stedman, R.C. A comparative analysis of predictors of sense of place dimensions: Attachment to, dependence on, and identification with lakeshore properties. J. Environ. Manag. 2006, 79, 316-327. [CrossRef] [PubMed]

40. Zhu, H.; Liu, B. Concepts analysis and research implications: Sense of place, place attachment and place identity. J. S. China Norm. Univ. 2011, 1, 1-8.

41. Moore, T. Planning for place: Place attachment and the founding of rural community land trusts. J. Rural. Stud. 2021, 83, 21-29. [CrossRef]

42. Soini, K.; Vaarala, H.; Pouta, E. Residents' sense of place and landscape perceptions at the rural-urban interface. Landsc. Urban Plan. 2012, 104, 124-134. [CrossRef]

43. Qian, J.; Zhu, H.; Liu, Y. Investigating urban migrants' sense of place through a multi-scalar perspective. J. Environ. Psychol. 2011, 31, 170-183. [CrossRef]

44. Tapsuwan, S.; Leviston, Z.; Tucker, D. Community values and attitudes towards land use on the Gnangara Groundwater System: A Sense of Place study in Perth, Western Australia. Landsc. Urban Plan. 2011, 100, 24-34. [CrossRef]

45. Hidalgo, M.; Hernández, B. Place attachment: Conceptual and empirical questions. J. Environ. Psychol. 2001, $21,273-281$. [CrossRef]

46. Kyle, G.; Mowen, A.J.; Tarrant, M. Linking place preferences with place meaning: An examination of the relationship between place motivation and place attachment. J. Environ. Psychol. 2004, 24, 439-454. [CrossRef]

47. Deutsch, K.; Goulias, K. Investigating the Impact of Sense of Place on Travel Behavior Using an Intercept Survey Methodology. St. Barbar. Univ. Calif. 2009, 887-908.

48. Stedman, R.C. Is It Really Just a Social Construction?: The Contribution of the Physical Environment to Sense of Place. Soc. Nat. Resour. 2003, 16, 671-685. [CrossRef]

49. Cross, J.E.; Keske, C.M.; Lacy, M.G.; Hoag, D.L.; Bastian, C.T. Adoption of conservation easements among agricultural landowners in Colorado and Wyoming: The role of economic dependence and sense of place. Landsc. Urban Plan. 2011, 101, 75-83. [CrossRef]

50. Xue, D.Q.; Chen, Q.; Lv, Y.Q. Land dependence and local attachment of rural residents in Weibei Upland under the background of land circulation: A comparative study of land-lost and normal farmers in Huangling County. J. Shaanxi Norm. Univ. 2019, 4, 31-39. [CrossRef]

51. Nan, M.-X.; Sen, Z.-Y.; Lei, Z.; Ying, X. Population structure and understory species diversity of different aged Pinus sylvestris var. mongolica plantations in Nenjiang Sandy Land of Northeast China. Chin. J. Appl. Ecol. 2012, 23, 2332. [CrossRef] 
52. Fu, B.J.; Chen, L.D.; Ma, K.M. The Effect of Land Use Change on the Regional Environment in the Yangjuangou Catchment in the Loess Plateau of China. Acta Geogr. Sin. 1999, 3, 51-56. [CrossRef]

53. Liu, Y.S.; Chen, Z.F.; Li, Y.R.; Feng, W.L.; Cao, Z. The Planting Technology and Industrial Development Prospects of Forage Rape in the Loess Hilly Area-A Case Study of Newly-increased Cultivated Land Through Gully Land Consolidation in Yan'an, Shaanxi Province. J. Nat. Resour. 2017, 32, 2065-2074. [CrossRef]

54. Wang, X.L.; Bao, Y.H. Study on the methods of land use dynamic change research. Prog. Geogr. 1999, 1, 3-5. [CrossRef]

55. Zhuang, D.; Liu, J. Modeling of regional differentiation of land-use degree in China. Chin. Geogr. Sci. 1997, 7, 302-309. [CrossRef]

56. Devine-Wright, P. Rethinking NIMBYism: The role of place attachment and place identity in explaining place-protective action. $J$. Community Appl. Soc. Psychol. 2009, 19, 426-441. [CrossRef]

57. Gieling, J.; Vermeij, L.; Haartsen, T. Beyond the local-newcomer divide: Village attachment in the era of mobilities. J. Rural. Stud. 2017, 55, 237-247. [CrossRef]

58. Zhu, H.; Wu, J.; Guo, S.; Huang, D.; Zhu, Q.; Ge, T.; Lei, T. Land use and topographic position control soil organic C and N accumulation in eroded hilly watershed of the Loess Plateau. Catena 2014, 120, 64-72. [CrossRef]

59. Zhang, X.; Deng, Y.; Hou, M.; Yao, S. Response of Land Use Change to the Grain for Green Program and Its Driving Forces in the Loess Hilly-Gully Region. Land 2021, 10, 194. [CrossRef]

60. Zhang, S.; Yang, D.; Yang, Y.; Piao, S.; Yang, H.; Lei, H.; Fu, B. Excessive Afforestation and Soil Drying on China's Loess Plateau. J. Geophys. Res. Biogeosci. 2018, 123, 923-935. [CrossRef]

61. Lyu, C.; Xu, Z. Crop production changes and the impact of Grain for Green program in the Loess Plateau of China. J. Arid. Land 2020, 12, 18-28. [CrossRef]

62. Tang, Q.; Xu, Y.; Li, Y. Assessment of farmers' sustainable livelihoods and future strategies on the Loess Plateau: Based on a survey of 1076 farmers in Yan'an City in Shaanxi Province and Guyuan City in Ningxia Hui Autonomous Region. Prog. Geogr. 2013, 32, 161-169. 